\section{A. Entomology \\ ISSN: $1687-8809$ \\ www.eajbs.eg.net}

\title{
Description of a new phytoseiid mite species (Acari: Phytoseiidae) from Egypt with a special reference to its biology
}

\author{
Amal H.M. Romeih ${ }^{1}$; Reham I.A. Abo-Shnaf ${ }^{2 *}$; M.F. Hassan ${ }^{1}$; Marguerite A. Rizk $^{2}$ \\ 1- Zoology and Agricultural Nematology Department, Faculty of Agriculture, Cairo \\ University, Giza, Egypt. \\ 2- Vegetable and Ornamental Acarology Department, Plant Protection Research Institute, \\ Agricultural Research Centre, Giza, Egypt. \\ *Correspondence author: Rehamaboshnaf@yahoo.com
}

\begin{abstract}
The adult female and male of the phytoesiid mite, Euseius plumerii Abo-Shanf \& Romeih sp. n. were collected from leaves of both White Frangipani (Plumeria alba) and Rose (Rosa hybrida cv. Huddly) at Giza Governorate, Egypt, then identified and described. Furthermore, the description of immature stages was also presented. The life history of this new species were documented on the two spotted- spider mite, Tetranychus urticae Koch movable stages which infested leaves of rose at three temperature degrees $(20,25$ and $30 \pm 2$ ${ }^{\circ} \mathrm{C}$ ) and relative humidity of $70 \pm 5 \%$. The results proved that, $30^{\circ} \mathrm{C}$ was the most suitable temperature degree which accelerated the life cycle, gave highly egg production and greatly prey consumption.
\end{abstract}

Key Words: Phytoesiidae, Euseius, Tetranychus urticae, Description, Life history, White Frangipani, Rose, Egypt.

\section{INTRODUCTION}

Family Phytoseiidae has received considerable attention worldwide because of their potential as natural enemies of phytophagous mites (McMurtry1984). The genus Euseius was erected by Wainstein in 1962 with Seiulus finlandicus Oudemans as its type species. The taxonomy and distribution of phytoseiids have been extensively studied in different parts of the world, as summarized by DeLeon (1966), Denmark \& Muma (1978), McMurtry (1983), Moraes \& McMurtry (1983), Congdon \& McMurtry (1985), Kandeel \& Nassar (1986), Aponte \& McMurtry (1997), Walter (1999), Moraes et al. (2004), Qayyum et al. (2004) and Bayan \& Merheb (2006). Many experiment on the biology of the genus Euseius were done by some authors on various prey substrates as presented by (Abou-Setta \& Childers, 1987; Furtado \& Moraes, 1998; Abd El-Halim et al., 2000 and Kasap, 2008). The present work deals with the description of a new species of genus Euseius, and throw some lights on the biology of this species which reared on the two-spotted spider mite immatures.

\section{MATERIALS AND METHODS}

The following species were found on leaves of both White Frangipani shrubs (Plumeria alba) at Faculty of Agriculture, Cairo University, Giza, Egypt, and rose ( $R$. hybrida cv. Huddly) at Orman botanical garden, Giza. Samples were taken to the laboratory to extract the mites. Collected mite individuals were cleared in Nessbit's solution for a few minutes and mounted in Hoyer's medium on microscope slides for identification. All of the 
mounted mites were identified to species level under a light microscope using appropriate taxonomic references. They were then drawing by drawing eyepiece. Setal nomenclature followed in this manuscript is given in accordance with Rowell et al. (1978) and Chant \& Hansell (1971) for dorsal and ventral surfaces, respectively. Dorsal and ventral idiosomal setal patterns are determined according to Chant and Yoshida-Shaul (1989, 1991). All measurements were given in micron unit $(\mu)$.

The culture of E. plumerii sp. n. was started with a gravid female collected from leaves of White Frangipani shrubs. The mites were reared on a freshly Beefsteak leaf (Acalypha wilkesiana) placed upside down on moisten cotton pad in plastic tray. Water was added when needed maintaining suitable moisture. An abundance of T. urticae was offered daily to the predator as a main source of food, then maintained at $30 \pm 2^{\circ} \mathrm{C}$ and $70 \pm 5 \% \mathrm{RH}$. Newly deposited eggs of the predator were transferred singly to Experimental Units (EU) each consisted of leaf disk ( $3 \mathrm{~cm}$ diameter), manufactured from White Frangipani leaves floating on water-soaked cotton bed (diameter $10 \mathrm{~cm}$ and $1 \mathrm{~cm}$ thick) placed lower side upon a Petri dish (12cm diameter). The leaves' borders were surrounded by Tangle-foot to confine the mite and prevent it from escaping. The cotton was saturated with water daily during the test period. A known number of prey immature stages were offered to the predator newly hatched larvae as a food. Observations were made twice daily. Records were made daily on the duration of developmental stages, the number of prey consumed and the number of laid eggs at each EU. The observations continued until the end of longevity period. The entire tests were run at different temperatures: 20,25 and $30 \pm 2{ }^{\circ} \mathrm{C}$. A total of 25 replicates per temperature degree were prepared.

Data were subjected to statically analysis by the aid of One Way ANOVA (F-test) with the computer programme (SAS Institute, 1988) which runs under WIN. The difference between means was determined by the help of Duncan's multiple range tests (Duncan, 1955) in this programme.

\section{RESULTS}

\section{Euseius plumerii Abo-Shanf \& Romeih sp. n.}

Diagnosis: The new species E. plumerii is similarly well with E. scutalis (AthiasHenriot), but it differs in the shape and length of spermatheca; addition to the fixed digit is bidentate while those of $E$. scutalis is unidentate. Furthermore, the new species possesses macrosetae only on genu, tibia and basitarsus IV, but it presented on genu I-IV, tibia and tarsus IV in E. scutalis.

Female (Figs. 1-6). Dorsum - With smooth shield, with 17 pairs of setae: one vertical (j1), nine laterals (j3, z2, z4, s4, Z1 [considered mediolateral by Muma (1961); sensu Muma et al. (1970)], S2, S4, S5, Z5), four dorsocentrals (j4, j5, j6, J2), two mediolaterals (z5, Z4) and one clunal (J5). Sublateral setae (r3, R1) inserted on lateral integument. Dorsal plate measured 352.5 long, 227.3 wide at s4 level, j1 38.1, j3 43.8, j4 21.7, j5 23, j6 37.7, J2 42.5, J5 4.8, z2 41.2, z4 54.2, z5 17.3, Z1 37.3, Z4 32.9, Z5 73.2, s4 70.6, S2 41.2, S4 29.9, S5 35.1, r3 27.7, R1 15.2. Five pairs of pores are distributed as follows: Between j4 and z4, posterior to s4, anterior to Z1, anterolateral to Z4, and anterolateral to S5. All setae are smooth. Peritreme- Extending forward to level of z2. Ventrum-Sternal shield smooth with three pairs of setae. Distances between St1 and St3 is 69.8, St2 and St2 is 71.5, St5 and St5 is 84.5. Two pairs of metapodal plates presented. Ventrianal shield smooth, vase-shaped, with two extended lateroanterior corners, measured 114.8 long, 58.9 wide at ZV2 level, 73.5 wide 
at anus level, with three pairs of setae and one pair of preanal elliptical pores (gv3) posteriorly to JV2. Chelicera - Cheliceral fixed digit bidentate (with two teeth), measured 28.2 long. Spermatheca - Cervix tubular, elongated, slightly budging out posteriorly, 50.3 long, atrium nodular, major duct thread-like; vesicle ball-like shaped. Legs - With distinct macrosetae presented only on leg IV, curved tipped; with the following lengths: Sge 65.9, Sti 48.1, St 80.6; chetotactic formula of genu II 2-2/0, 2/0-1; genu III 1-2/1, 2/0-1.

Male (Figs. 7-8). Dorsum - With smooth shield, measured 238.5 long, 165 wide at s4 level, j1 29.5, j3 33.4, j4 18.6, j5 15.6, j6 23.8, J2 26.9, J5 3.9, z2 32.9, z4 39.4, z5 14.7, Z1 21.2, Z4 26, Z5 48.5, s4 53.7, S2 30.3, S4 21.2, S5 28.2, r3 23.8, R1 15.2. All setae are smooth. Peritreme - Extending anteriorly almost to level of z2. Ventrum - Sternogenital plate smooth. Ventrianal shield subtriangular, smoothed, measured 104 long, 141.3 wide at anterior corners, with three pairs of preanal simple setae; pores gv3 posteriorly to JV2. Chelicera Shaft of spermatodactyl measured 31.2 long. Legs - With macrosetae of the following lengths: Sge IV 49.8, Sti IV 36.4, St IV 61.1; chaetotaxy as in female.

Egg (Fig. 9). Nearly oval, measured 222.3 long and 171.2 wide; whitish translucent when newly deposited.

Larva (Figs. 10-12). Dorsum - Idiosoma measured 205.4 long, 169 wide at s4 level. Podonotal shield with nine pairs of simple setae, j1 21.7, j3 9.1, j4 6.1, j5 7.4, j6 29.5, z2 12.6, z4 17.3, z5 5.2, s4 64.1. Opithonotal shield with two pairs of simple setae, Z4 15.2, S4 3.9. Z5 166. Peritreme - Lacking. Ventrum - Sterogenital region with three pairs of simple setae. Distances between St1 and St3 is 72.4, St2 and St2 is 67.2. Ventral region with five pairs of simple setae. Anal opening surround with three setae. One pair of preanal pores (gv3) posteriorly to JV2. Chelicera - Cheliceral fixed digit bidentate, measured 19.1 long. Legs With macrosetae of the following lengths: Sge III 65.9, Sti III 48.1, St III 80.6; chetotactic formula of genu II 1-2/0, 2/0-1; genu III 1-2/0, 2/0-1.

Protonymph (Figs. 13-15). Dorsum: With entire shield, measured 246.1 long, 184.2 wide at s4 level. With 17 pairs of setae: j1 22.5, j3 23.4, j4 13.9, j5 13, j6 23.8, J2 18.2, J5 4.8, z2 24.7, z4 30.8, z5 9.5, Z1 17.3, Z4 22.1, Z5 39.4, s4 52, S2 25.6, S4 18.6, S5 16.9, r3 19.1, R1 11.7. All setae are smooth. Peritreme - Extending to level of j6. Ventrum Sterogenital region bears three pairs of sternal setae. Distances between St1 and St3 is 69.8, $\mathrm{St} 2$ and $\mathrm{St} 2$ is 56.3. Ventral region with four pairs of setae. Anal opening surround with three setae and one pair of preanal elliptical pores (gv3) posteriorly to JV2. Chelicera - Cheliceral fixed digit bidentate, measured 17.3 long. Legs - With macrosetae of the following lengths: Sge IV 57.2, Sti IV 55.5, St IV 69.3; chetotactic formula of genu II 1-2/0, 2/0-1; genu III 1$2 / 0,2 / 0-1$.

Female deutonymph (Figs. 16-18). Dorsum - With smooth shield, measured 291.8 long, 229.5 wide at s4 level. With 17 pairs of setae: j1 33.4, j3 36.4, j4 16.9, j5 17.3, j6 29.5, J2 32.5, J5 6.1, z2 35.1, z4 41.2, z5 16.5, Z1 29.5, Z4 31.6, Z5 58.1, s4 67.2, S2 37.7, S4 26, S5 27.7, r3 24.7, R1 17.8. Five pairs of pores are distributed as follows: Between j4 and z4, posterior to s4, anterior to $\mathrm{Z1}$, anterolateral to $\mathrm{Z4}$, and anterolateral to S5. All setae are smooth. Peritreme - Reached level of z4. Ventrum - Sterogenital region bears five pairs of sternal setae. Distances between St1 and St3 is 73.2, St2 and St2 is 66.7, St5 and St5 is 44.6. Ventral region bears seven pairs of setae. Anal opening surround with three setae and one pair of preanal elliptical pores (gv3) posteriorly to JV2. Chelicera - Cheliceral fixed digit bidentate, measured 25.1 long. Legs - With macrosetae of the following lengths: Sge IV 59.4, Sti IV 49, St IV 73.2; chetotactic formula of genu II 2-2/0, 2/0-1; genu III 1-2/1, 2/0-1. 
Male deutonymph (Fig. 19). Resembles female deutonymph but smaller and differs in absence of lateroventral setae.

Type material: Holotype female was collected from leaves of White Frangipani shrubs at Faculty of Agriculture, Cairo University, Giza, Egypt, on February 18, 2006. Paratypes, several adult females collected from rose leaves in Orman botanical garden, Giza Governorate in 2006. Allotypes, several adult males collected with same data.

Etymology: plumerii, in homage to the plant species, which the type specimens collected from.

\section{Biological studies}

The female and male egg's incubation period increased with the decline in temperature degrees. Large effects of temperature degrees were recorded, whereas the longest life cycle averaged $12 \& 10.54$ days for both female and male; respectively was obtained at $20^{\circ} \mathrm{C}$, compared with those reared at $30^{\circ} \mathrm{C}$ averaged $6.43 \& 5.3$ days (Table 1 ).

Table 1: Effect of temperature degrees on the duration of E. plumerii sp. n. different stages in days reared on $T$. urticae immatures infested rose leaves (R. hybrida cv. Huddly) at $70 \pm 5 \% \mathrm{RH}$

\begin{tabular}{|c|c|c|c|c|c|}
\hline \multirow{2}{*}{$\begin{array}{l}\text { Developmental } \\
\text { stages }\end{array}$} & \multirow{2}{*}{ Sex } & & \multicolumn{3}{|c|}{ Temperature degrees } \\
\hline & & & $20{ }^{\circ} \mathrm{C}$ & $25^{\circ} \mathrm{C}$ & $30{ }^{\circ} \mathrm{C}$ \\
\hline \multirow{2}{*}{ Egg } & 우 & & $5.00 \pm 0.82 \mathrm{a}$ & $4.43 \pm 0.53 \mathrm{a}$ & $2.29 \pm 0.49 \mathrm{~b}$ \\
\hline & $\hat{0}$ & & $4.00 \pm 0.76 \mathrm{a}$ & $3.50 \pm 0.53 \mathrm{a}$ & $1.63 \pm 0.52 b$ \\
\hline \multirow{4}{*}{ Larva } & \multirow{2}{*}{ ㅇ } & A & $1.14 \pm 0.13 \mathrm{a}$ & $0.93 \pm 0.12 b$ & $0.46 \pm 0.09 \mathrm{c}$ \\
\hline & & Q & $0.96 \pm 0.34 \mathrm{a}$ & $0.82 \pm 0.24 \mathrm{a}$ & $0.43 \pm 0.19 b$ \\
\hline & \multirow{2}{*}{ o } & A & $1.06 \pm 0.12 \mathrm{a}$ & $0.81 \pm 0.12 b$ & $0.41 \pm 0.13 \mathrm{c}$ \\
\hline & & Q & $0.88 \pm 0.33 \mathrm{a}$ & $0.75 \pm 0.23 a$ & $0.38 \pm 0.13 b$ \\
\hline \multirow{4}{*}{ Protonymph } & \multirow{2}{*}{ q } & A & $1.21 \pm 0.09 \mathrm{a}$ & $0.96 \pm 0.09 \mathrm{~b}$ & $0.79 \pm 0.09 \mathrm{c}$ \\
\hline & & Q & $1.04 \pm 0.22 \mathrm{a}$ & $0.86 \pm 0.20 \mathrm{ab}$ & $0.71 \pm 0.22 \mathrm{~b}$ \\
\hline & \multirow{2}{*}{$\widehat{0}$} & A & $1.19 \pm 0.12 \mathrm{a}$ & $0.94 \pm 0.18 b$ & $0.69 \pm 0.12 \mathrm{c}$ \\
\hline & & Q & $1.00 \pm 0.30 \mathrm{a}$ & $0.78 \pm 0.21 b$ & $0.66 \pm 0.27 b$ \\
\hline \multirow{4}{*}{ Deutonymph } & \multirow{2}{*}{ 우 } & A & $1.36 \pm 0.20 \mathrm{a}$ & $1.00 \pm 0.14 \mathrm{~b}$ & $0.93 \pm 0.12 b$ \\
\hline & & Q & $1.29 \pm 0.30 \mathrm{a}$ & $0.89 \pm 0.13 \mathrm{~b}$ & $0.82 \pm 0.28 \mathrm{~b}$ \\
\hline & $\lambda$ & A & $1.25 \pm 0.19 \mathrm{a}$ & $0.97 \pm 0.09 \mathrm{~b}$ & $0.78 \pm 0.09 \mathrm{c}$ \\
\hline & O & Q & $1.16 \pm 0.30 \mathrm{a}$ & $0.88 \pm 0.19 b$ & $0.75 \pm 0.35 \mathrm{~b}$ \\
\hline \multirow{2}{*}{ Total immature stages } & 우 & & $7.00 \pm 0.58 \mathrm{a}$ & $5.46 \pm 0.44 \mathrm{~b}$ & $4.14 \pm 0.32 \mathrm{c}$ \\
\hline & $\hat{0}$ & & $6.54 \pm 0.49 \mathrm{a}$ & $5.13 \pm 0.50 \mathrm{~b}$ & $3.67 \pm 0.38 \mathrm{c}$ \\
\hline \multirow{2}{*}{ Life cycle } & 우 & & $12.00 \pm 0.65 \mathrm{a}$ & $9.89 \pm 0.43 \mathrm{~b}$ & $6.43 \pm 0.40 \mathrm{c}$ \\
\hline & $\hat{\sigma}$ & & $10.54 \pm 0.62 \mathrm{a}$ & $8.63 \pm 0.57 \mathrm{~b}$ & $5.30 \pm 0.57 \mathrm{c}$ \\
\hline
\end{tabular}

Numbers in each column followed by different letters are significantly different $(P=0.05$; Duncan's Multiple Range Test).

Mating was essential for reproduction and multiple mating was important to complete reproduction, where it takes place after final moult (Hoy and Smilanick, 1979). Mating usually takes several hours $(5-7 \mathrm{~h})$ during the first copulation, while it decreases gradually during other ones. The male can mate more than one female and the latter accepted more than once. When the temperature slightly changed from 20 to $30^{\circ} \mathrm{C}$, the oviposition period decreased from 17.29 to 9.43 days (Table 2).

Table 2: Longevity and life span of E. plumerii sp. n. reared on T. urticae immatures infested rose leaves (R. hybrida cv. Huddly) at three temperature degrees and $70 \pm 5 \% \mathrm{RH}$

\begin{tabular}{ccccc}
\hline & Sex & \multicolumn{3}{c}{ Temperature degrees } \\
\cline { 2 - 5 } & & $20{ }^{\circ} \mathrm{C}$ & $25{ }^{\circ} \mathrm{C}$ & $30{ }^{\circ} \mathrm{C}$ \\
\hline Pre-oviposition & + & $1.86 \pm 0.69 \mathrm{a}$ & $1.36 \pm 0.48 \mathrm{a}$ & $1.29 \pm 0.49 \mathrm{a}$ \\
Generation & + & $13.86 \pm 0.75 \mathrm{a}$ & $11.25 \pm 0.61 \mathrm{~b}$ & $7.72 \pm 0.44 \mathrm{c}$ \\
Oviposition & + & $17.29 \pm 0.76 \mathrm{a}$ & $13.57 \pm 0.79 \mathrm{~b}$ & $9.43 \pm 0.79 \mathrm{c}$ \\
Post-oviposition & + & $1.96 \pm 0.59 \mathrm{a}$ & $1.86 \pm 0.24 \mathrm{a}$ & $1.36 \pm 0.35 \mathrm{~b}$ \\
Longevity & + & $21.11 \pm 0.71 \mathrm{a}$ & $16.79 \pm 0.86 \mathrm{~b}$ & $12.08 \pm 72 \mathrm{c}$ \\
& 0 & $17.63 \pm 0.68 \mathrm{a}$ & $11.34 \pm 0.83 \mathrm{~b}$ & $8.47 \pm 0.82 \mathrm{c}$ \\
Life span & + & $33.11 \pm 0.71 \mathrm{a}$ & $26.68 \pm 0.91 \mathrm{~b}$ & $18.51 \pm 0.61 \mathrm{c}$ \\
& + & $28.17 \pm 0.52 \mathrm{a}$ & $19.97 \pm 0.88 \mathrm{~b}$ & $13.77 \pm 0.50 \mathrm{c}$ \\
\hline
\end{tabular}


The highest mean number of eggs (55.14/female) with the highest daily oviposition rate (5.85 eggs/day) was observed at $30^{\circ} \mathrm{C}$, the lowest daily oviposition rate ( 2.79 eggs/day) was obtained at $20^{\circ} \mathrm{C}$ with a total of 48.29 eggs/female (Fig. 20).

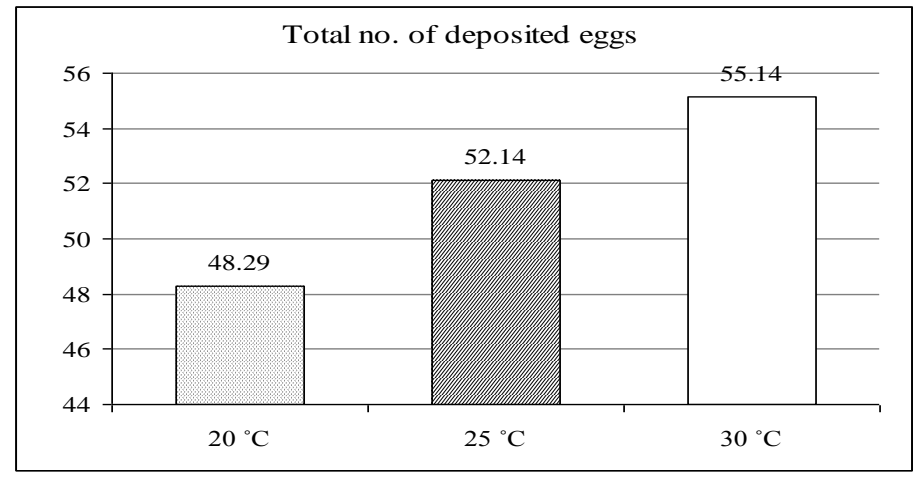

Fig. 20: Fecundity of the predatory mite, E. plumerii sp. n. reared on T. urticae immatures infested rose leaves (R. hybrida cv. Huddly) at three temperature degrees and $70 \pm 5 \% \mathrm{RH}$

Larvae of some species of genus Euseius had been reported feed (Takafuji \& Chant, 1976 and Momen, 1995). The larva of female and male of this species sucked (4 \& 3), (6.86 \& 5.75) and (7.29 \& 6.25) immatures of T. urticae at 20,25 and $30^{\circ} \mathrm{C}$, respectively (Table 3). Adult female and male of the predatory mite, E. plumerii sp. n. consumed the higest numbers of the prey at $30^{\circ} \mathrm{C}(326.86 \& 184.13$ immatures) in caparisoning with those noticed at the others.

No agreeing with the findings of Kasap and Şekeroğlu (2004) who determined results with the biology and reproductive potential of E. scutalis using a diet of all life stages of the spider mite, Panonychus citri (McGregor), whereas the oviposition period was longer at $25^{\circ} \mathrm{C}$ than at 20 and $30^{\circ} \mathrm{C}$, but the present result reported it prolonged at $20^{\circ} \mathrm{C}$.

Table 3: Effect of temperature degrees on the consumption rate per day of E. plumerii sp. n. reared on T. urticae immatures infested rose leaves (R. hybrida cv. Huddly) at $70 \pm 5 \% \mathrm{RH}$

\begin{tabular}{|c|c|c|c|c|c|}
\hline \multirow{2}{*}{ Developmental stages } & \multirow{2}{*}{ Sex } & & \multicolumn{3}{|c|}{ Temperature degrees } \\
\hline & & & $20^{\circ} \mathrm{C}$ & $25^{\circ} \mathrm{C}$ & $30{ }^{\circ} \mathrm{C}$ \\
\hline \multirow{4}{*}{ Larva } & \multirow{2}{*}{ q } & Mean & $4.00 \pm 1.15 \mathrm{c}$ & $6.86 \pm 0.69 \mathrm{~b}$ & $7.29 \pm 1.25 \mathrm{a}$ \\
\hline & & Daily rate & $3.46 \pm 0.77 \mathrm{c}$ & $7.57 \pm 1.76 b$ & $16.00 \pm 2.31 \mathrm{a}$ \\
\hline & \multirow{2}{*}{$\hat{0}$} & Mean & $3.00 \pm 1.07 \mathrm{c}$ & $5.75 \pm 0.71 \mathrm{~b}$ & $6.25 \pm 1.91 \mathrm{a}$ \\
\hline & & Daily rate & $2.90 \pm 1.19 \mathrm{c}$ & $7.17 \pm 1.17 \mathrm{~b}$ & $15.50 \pm 0.93 \mathrm{a}$ \\
\hline \multirow{4}{*}{ Protonymph } & \multirow{2}{*}{ 우 } & Mean & $20.86 \pm 0.90 \mathrm{c}$ & $22.14 \pm 0.90 \mathrm{~b}$ & $23.43 \pm 1.27 \mathrm{a}$ \\
\hline & & Daily rate & $17.29 \pm 1.79 \mathrm{c}$ & $23.14 \pm 2.27 \mathrm{~b}$ & $30.00 \pm 1.92 \mathrm{a}$ \\
\hline & \multirow{2}{*}{$\hat{0}$} & Mean & $17.63 \pm 2.00 \mathrm{c}$ & $18.25 \pm 2.60 \mathrm{~b}$ & $19.25 \pm 2.76 \mathrm{a}$ \\
\hline & & Daily rate & $14.90 \pm 1.81 \mathrm{c}$ & $19.75 \pm 1.83 \mathrm{~b}$ & $28.17 \pm 1.81 \mathrm{a}$ \\
\hline \multirow{4}{*}{ Deutonymph } & \multirow{2}{*}{ 우 } & Mean & $24.71 \pm 2.75 \mathrm{c}$ & $26.29 \pm 2.06 \mathrm{~b}$ & $28.29 \pm 2.93 \mathrm{a}$ \\
\hline & & Daily rate & $18.46 \pm 2.68 \mathrm{c}$ & $26.53 \pm 2.16 \mathrm{~b}$ & $30.57 \pm 0.98 \mathrm{a}$ \\
\hline & \multirow{2}{*}{$\hat{0}$} & Mean & $21.38 \pm 1.30 \mathrm{c}$ & $22.63 \pm 1.30 \mathrm{~b}$ & $23.25 \pm 1.16 \mathrm{a}$ \\
\hline & & Daily rate & $17.43 \pm 2.72 \mathrm{c}$ & $23.46 \pm 1.50 \mathrm{~b}$ & $29.96 \pm 2.35 \mathrm{a}$ \\
\hline \multirow{4}{*}{ Adult } & \multirow{2}{*}{ 우 } & Mean & $244.43 \pm 0.79 \mathrm{c}$ & $294.14 \pm 0.90 \mathrm{~b}$ & $326.86 \pm 0.90 \mathrm{a}$ \\
\hline & & Daily rate & $11.59 \pm 0.40 \mathrm{c}$ & $17.56 \pm 0.93 \mathrm{~b}$ & $27.16 \pm 1.54 \mathrm{a}$ \\
\hline & \multirow{2}{*}{$\hat{\sigma}$} & Mean & $95.25 \pm 0.71 \mathrm{c}$ & $108.25 \pm 0.89 \mathrm{~b}$ & $184.13 \pm 0.83 \mathrm{a}$ \\
\hline & & Daily rate & $5.41 \pm 0.22 \mathrm{c}$ & $9.59 \pm 0.77 \mathrm{~b}$ & $21.92 \pm 2.12 \mathrm{a}$ \\
\hline
\end{tabular}

Numbers in each column followed by different letters are significantly different $(P=0.05$; Duncan's Multiple Range Test). 


\section{REFERENCES}

Abd El-Halim, Salwa M.; Hanna, M. A.; Abdella, M. M. and Ramadan, M. F. (2000). Evaluation of food type, availability of food and competition as facfors affecting mass rearing of the predaceous mite Eusejus scutalis (Athias-Henriot) (Acari-Phytoseiidae). Egypt. J. Biol. P. Cont., 10 (1\&2):28-33.

Abou-Setta, M. M. and Childers, C. C. (1987). Biology of Euseius mesembrinus (Acari: Phytoseiidae): life tables on ice plant pollen at different temperatures with notes on behavior and food range. Exp. Appl. Acarol., 3 (2):123-130.

Aponte, O. and McMurtry, J. A. (1997). Description of Euseius obispensis n. sp. (Acari: Phytoseiidae) from Avocado in California. Internat. J. Acarol., 23(1):21-25.

Bayan, A. and Merheb, B. (2006). Descriptions of two new phytoseiid mites (Acari: Mesostigmata: Gamasina) found in a grapevine orchard from Lebanon. Sys. Appl. Acarol., 11:51-56.

Chant, D. A. and Hansell, R. I. C. (1971). The genus Amblyseius (Acarina: Phytoseiidae) in Canada and Alaska. Can. J. Zool., 49:703-758.

Chant, D.A. and Yoshida-Shaul, E. 1989. Adult dorsal setal patterns in the family Phytoseiidae (Acari: Gamasina). Internat. J. Acarol., 15:219-233.

Chant, D. A. and Yoshida-Shaul, E. (1991). Adult ventral setal patterns in the family Phytoseiidae (Acari: Gamasina). Internat. J. Acarol., 17:187-199.

Congdon, B. D. and McMurtry. J. A. (1985). Biosystematics of Eusieus on Claifornia citrus and Avocado with the description of a new species (Acari: Phytoseiidae). Internat. J. Acarol., 11(1):23-30.

DeLeon, D. (1966). Phytoseiidae of British Guiana with keys to species (Acarina: Mesostigmata). In studies on the fauna of Suriname and other Guyanas, 8:81-102.

Denmark, H.A. and Muma, M.H. 1978. Phytoseiidae of Jamaica and annotated list (Acarina: Mesostigmata). Internat. J. Acarol., 4(1):1-22.

Duncan, D. B. (1955). Multiple range and multiple F-test. Biometrics, 11:1-45.

Furtado, I. P. and Moraes, G. J. de. (1998). Biology of Euseius citrifolius, a candidate for the biological control of Mononychellus tanajoa (Acari: Phytoseiidae, Tetranychidae). Sys. Appl. Acarol., 3:43- 48.

Hoy, M. A. and Smilanick, J. M. (1979). A sex pheromone by immature and adult females of the predatory mite, Metaseiulus occidentalis (Nesbitt). Entomol. Exp. Appl., 26:97104.

Kandeel, M. M. H. and Nassar, O. A. (1986). Field observations on the predatory mites of citrus pests along with a key to the Egyptian species (Acari). Bull. Soci. Entomol. Egypt, 66:169-176.

Kasap, İ. (2008). Influence of temperature on life table parameters of the predaceous mite, Euseius finlandicus (Oudemans) (Acari: Phytoseiidae). Turk. J. Agric. For., 32:1-8.

Kasap, İ. and Şekeroğlu, E. (2004). Life history of Euseius scutalis feeding on citrus red mite Panonychus citri at various temperatures. BioControl, 49 (6):645-654.

McMurtry, J. A. (1983). A Phytoseiidae mite from Guatemala with descriptions of two new species and redefinitions of the genera Eusieus, Typhloseiopsis, and the Typhlodromus occidentalis species group (Acari: Mesostigmata). Internat. J. Entomol., 25(4):249-272.

McMurtry, J. A. (1984). A consideration of the role of predators in the control of acarine pests, pp. 109-121 in D.A. Griffiths, and C.E. Bowman (eds.). Acarology VI, v. 1, Ellis Horwood Ltd., New York. 
Momen, Faten M. (1995). Feeding, development and reproduction of Amblyseius barkeri (Acari:Phytoseiidae) on various kinds of food substrates. Acarologia, 36(2):101-105.

Moraes, G. J.de and McMurtry, J. A. (1983). Phytoseiid mites (Acarina) of northeastern Brazil with descriptions of four new species. Internat. J. Acarol., 9 (3):131-148.

Moraes, G. J. de; Lopes, P. C. and Fernando, L. C. P. (2004). Phytoseiid mites (Acari: Phytoseiidae) of coconut growing areas in Sri Lanka, with descriptions of three new species. J. Acarol. Soc. Jpn., 13 (2):141-160.

Muma, M. H. (1961). Subfamilies, genera, and species of Phytoseiidae (Acarina: Mesostigmata). Florida St. Mus. Bull. Biol. Sci., 5:267-302.

Muma, M. H.; Denmark, H. A. and Deleon, D. (1970). Phytoseiid of Florida. Arthropods of Florida and neighboring land areas, 6. Florida Dept. Agr. Cons. Serv., Div. Plant Ind., Gainesville, $150 \mathrm{pp}$.

Qayyum, S.; Pervez, I. and Afzal, M. (2004). New species of the genus Euseius (Acarina: Phytoseiidae) from northern areas of Pakistan. Pak. J. Agri. Sci., 41(3-4):146-151.

Rowell, H. J.; Chant, D. A. and Hansell, R. I. C. (1978). The determination of setal homologies and setal patterns on the dorsal shield in the family Phytoseiidae (Acarina: Mesostigmata). Can. Entomol., 110:859-876.

SAS Institute. (1988). SAS/STAT User's Guide, Ver. 6.03. SAS Institute Inc., Cary, North Carolina, USA.

Takafuji, A. and Chant, D. A. (1976). Comparative studies on two species of predacious phytoseiid mites (Acari: Phytoseiidae), with special reference to their responses to the density of their prey. Res. Popup. El., 17:255-309.

Walter, D. E. (1999). Review of Australian Asperoseius Chant, Euseius Wainstein, Okiseius Ehara and Phtoscutu Muma (Acari: Mesostigmata: Phytosiidae) with a key to the genera of Australian Amblyseiinae and description of two new species. Aust. J. Entomol., 38:85-95. 

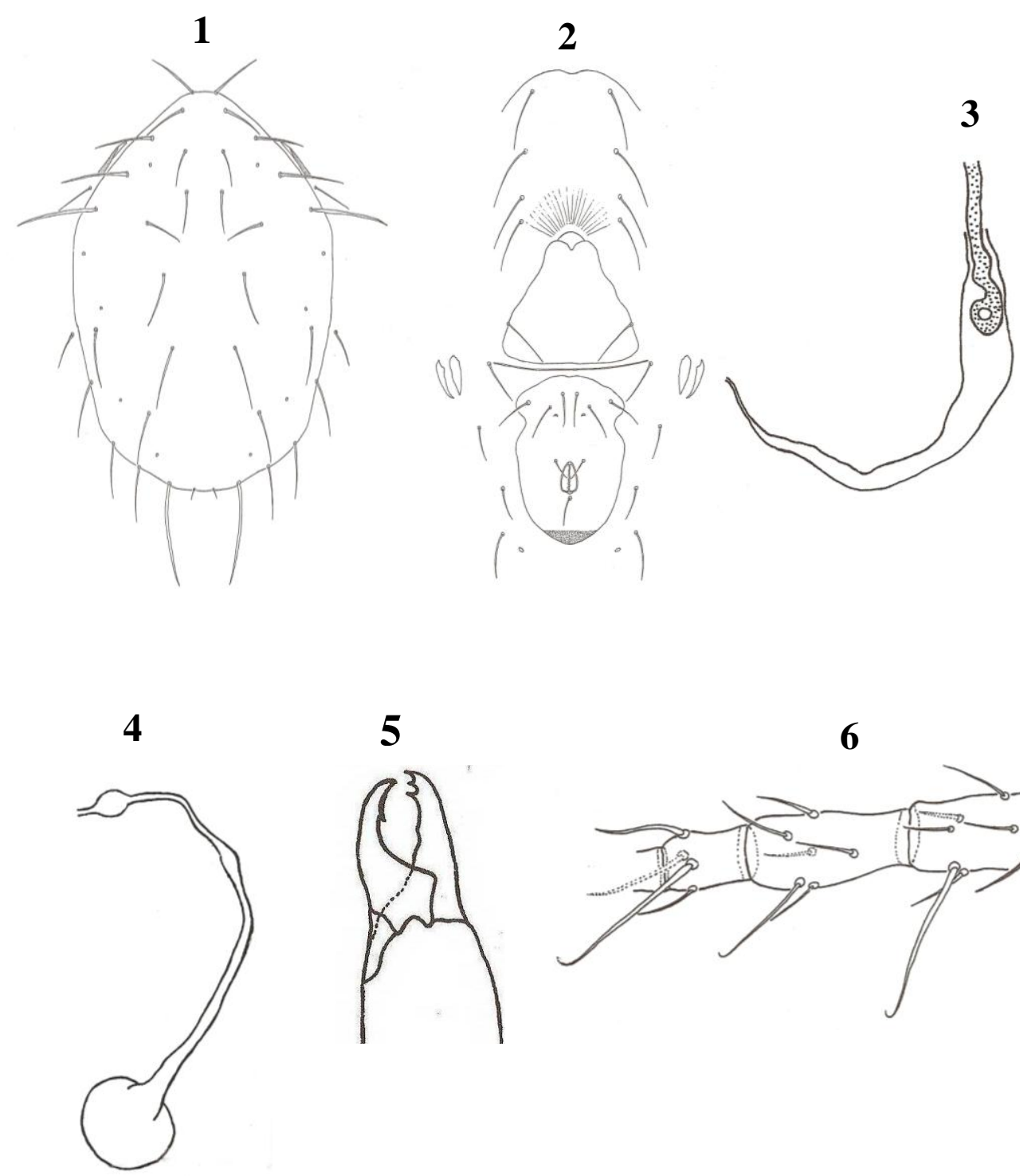

5

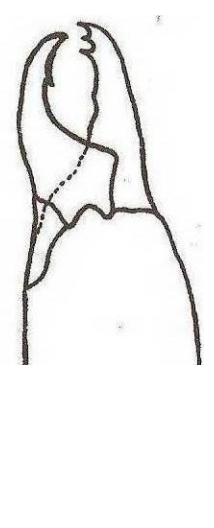

7

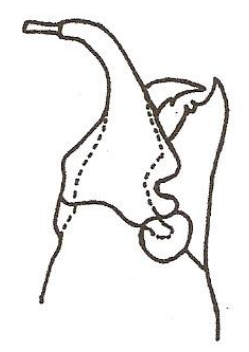

6

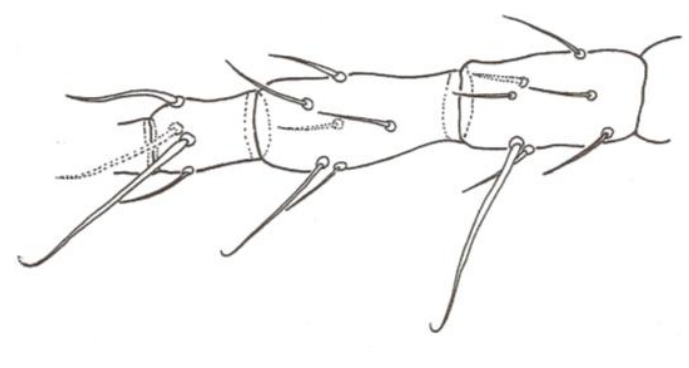

8

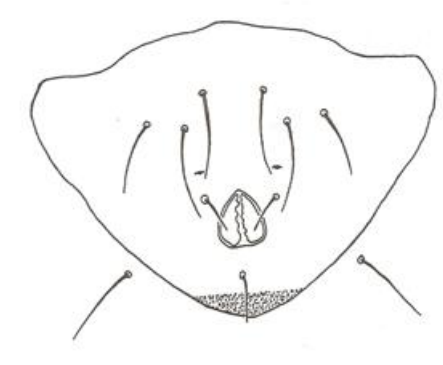

Figs. 1- 8: Euseius plumerii sp.n. female. 1. Dorsal shield, 2. Ventral surface, 3. Peritreme and peritremal plate, 4. Spermatheca, 5. Chelicerae, 6. Setaion of genu, tibia and basitarsus of leg IV, 7. Spermatodactyle, 8. Male ventrianal shield. 


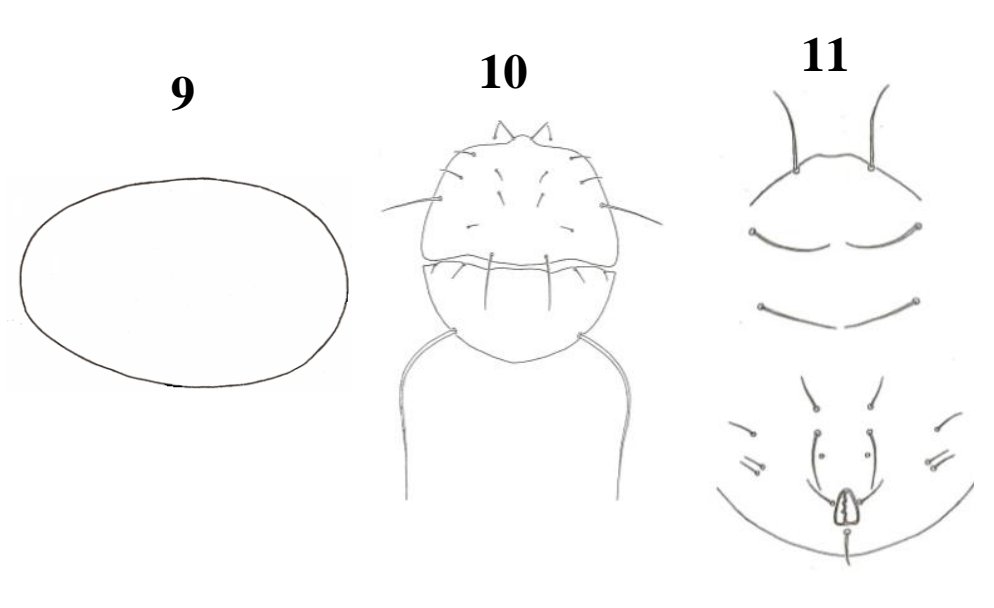

\section{4}
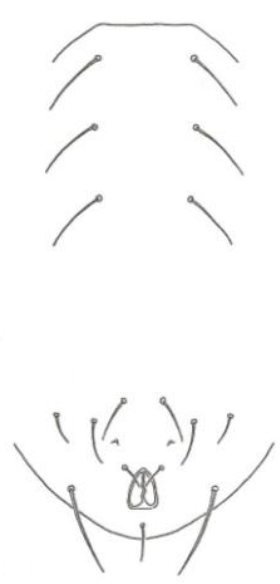

16

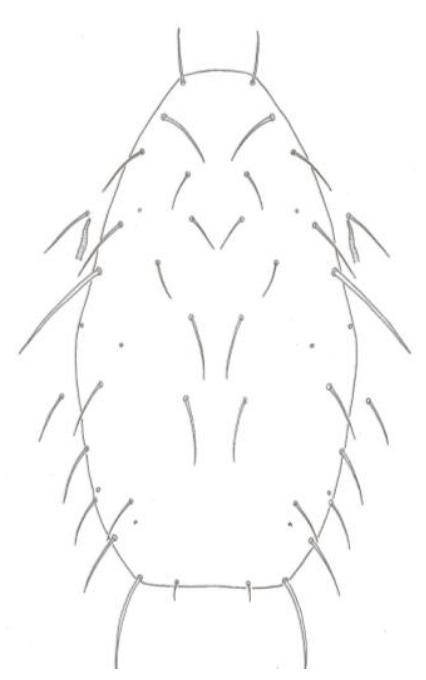

13

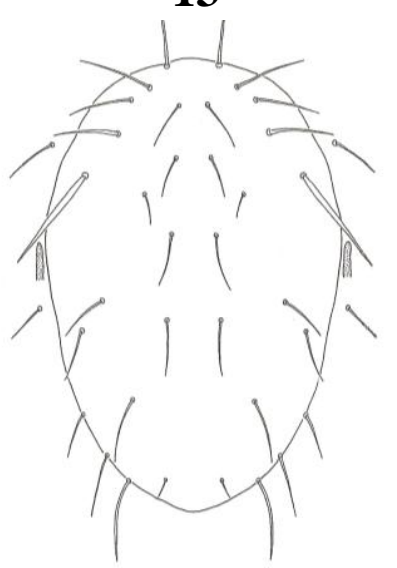

17

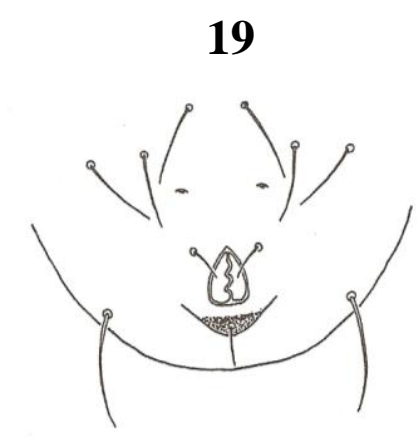

12
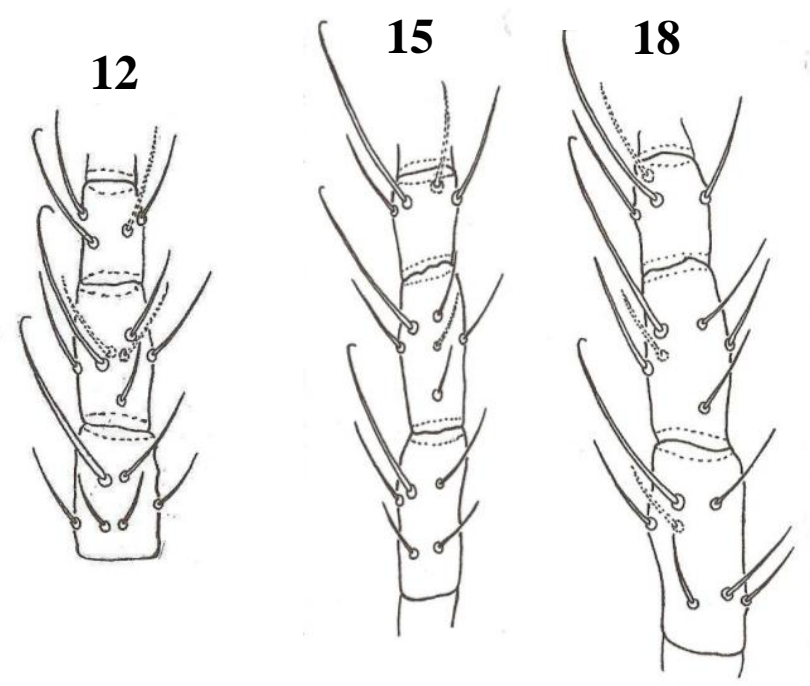

Figs. 9-19: Euseius plumerii sp.n. 9. Egg, 10-11. Larva dorsal and ventral surface, 12. Larva setation of genu, tibia and basitarsus of leg III, 13-14. Protonymph dorsal and ventral surface, 15. Protonymph setation of genu, tibia and basitarsus of leg IV, 16-17. Female deutonymph dorsal and ventral surface, 18. Deutonymph setation of genu, tibia and basitarsus of leg IV, 19. Male deutonymph ventral region. 


\section{ARABIC SUMMARY}

\section{وصف نوع جديد يتبع عائلة Phytoseiidae في مصر مع الإشارة إلى البيولوجي الخاص به

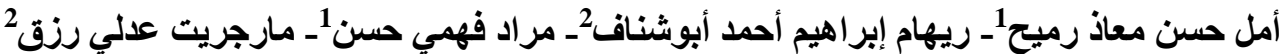

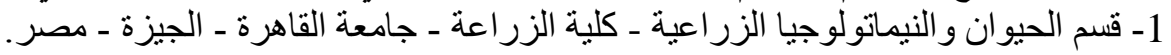 2- معهد بحوث وقاية النباتات ـ مركز البحوث الندات الزر اعية ـ الدقي ـالجيزة ـ مصر.}

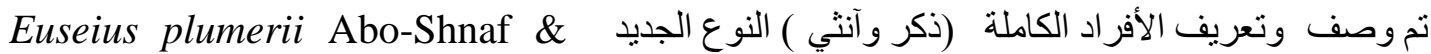
Romeih

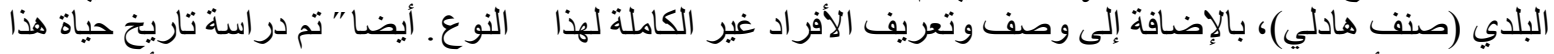

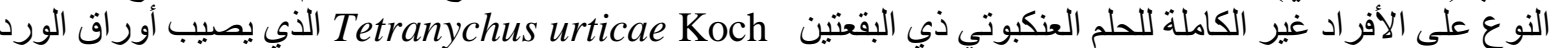

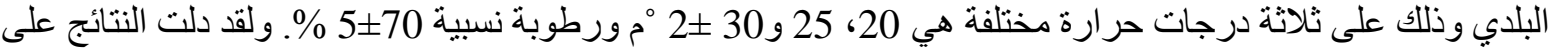

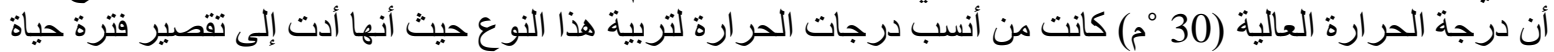

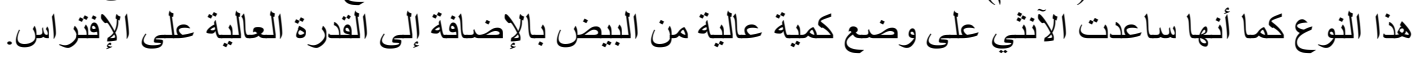

